\title{
Porcelain Veneer
}

National Cancer Institute

\section{Source}

National Cancer Institute. Porcelain Veneer. NCI Thesaurus. Code C52584.

A restoration consisting of a layer of tooth-colored porcelain material cemented to the surface of a tooth. 